\title{
Notes on the Translation
}

Words that appear in English in Baudrillard's original text, a practice that becomes increasingly prevalent in his writings, have been noted as such. Baudrillard rarely provides full citations in his own notes. The editor and translators have attempted to complete the citation, but in some cases this has proven impossible. At times Baudrillard cites French translations of English or American works which are unavailable in the United States. At other times Baudrillard's quotations have not been located anywhere in the text he cites. [Trans.] indicates a translator's addition to the notes.

\section{EDITOR's NOTE}

We have preserved the spelling and punctuation practices of the translations we have taken from elsewhere. Our own translations use American spelling and punctuation practices. 